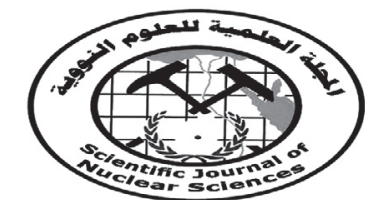

ISSN 2314-5609

Nuclear Sciences Scientific Journal

vol. 1 , p $133-140$

2012

Nuclear Materials Authority

P.O.Box 530 Maadi, Cairo, Egypt

\title{
EFFECT OF RADIO-ELEMENTS IN THE BLACK SANDS ON WILD PLANT THAT GROWN EASTERN AND WESTERN ROSETTA BRANCH, EGYPT.
}

\author{
MOHAMED E.E. AL-SHOBAKI and ALI M. A. MASHOUR ${ }^{1}$ \\ Nuclear Materials Authority, Cairo, Egypt ;Soil and Water Dep. Fac. of Agric .Al-Azhar Univ. ${ }^{1}$
}

\begin{abstract}
The black-sand deposits are widely distributed alongside the Mediterranean Sea coast from Abu-Quir in the west to Rafah city in the extreme east. It contains, minerals, which is considered as the main source of uranium, thorium, potassium and iron oxides as a heavy and / or radio elements. These elements may be transferred with irrigation water to the plant organ (s), or even prevented the adsorption of nutrients. To achieve this purpose, surface soil samples $(0-30 \mathrm{~cm}$.) and subsurface soil samples $(30-60 \mathrm{~cm})$ were collected from eastern and western of Rosetta area., also Aerva plants samples (roots, stems, leaves and flowers) as a wild plant were collected from these areas to evaluate the object of this study..The results showed highest values of thorium, uranium, potassium and iron detected in soil and plant samples near Rosetta estuary at two sides (eastern and western). The available N. P. K. and Fe in western soil samples were higher than that obtained by eastern soil samples. The N. P. K. content of the plant organ (s) samples that grown at western side were higher than that found the eastern side. The highest thorium, uranium and iron content found in plant root and the least were in the leaves or flowers plants, at two Rosetta sides. Also, total uranium, thorium and iron content in western side were higher than eastern side soil samples.
\end{abstract}

\section{INTRODUCTION}

The present work was conducted to evaluate the effect of radio elements in the black sands of eastern and western Rosetta branch, Egypt on macro and micro-elements of Aerva plants. The agricultural development represents the main solution for facing the drastic demands for food, all over the world. The development may be occurred through several ways. One of them in the Northern Delta area is raising the soil surface level by adding some sandy layers. These sandy layers most probably will contain black-sand and some wild plants. However, the greatest part of the blacksand was found in Rosetta area, and possibly the largest known accumulations of blacksands on the African coast, (Davidson, 1950).
The black-sands contain some heavy and radioactive minerals. The radioactive minerals contain potassium, uranium and thorium. Although, potassium is one of macronutrient for plants was undergoes a simple from radioactive decay. The decay of uranium and thorium proceeds sequentially along a chain disintegrations (IAEA 1979). Uranium content of soil is highly variable with values ranging from 1 to $8 \mathrm{ppm}$, the average being about $1 \mathrm{ppm}$, (IAEA, 1988).

\section{MATERIALS AND METHODS}

Twenty soil samples surface $(0-30 \mathrm{~cm})$ and subsurface $(30-60 \mathrm{~cm}$.) depths were collected from virgin soil on both eastern and western sides of Rosetta estuary area at distances were 100,150, 200, 250 and $300 \mathrm{~m}$ in both two sides. Also, forty plant samples were 
collected from the same distances of eastern and western sides of Rosetta estuary.

The soil samples were air dried, ground passed through $2 \mathrm{~mm}$ sieve and analyzed according to Jackson (1973). Thorium, uranium and potassium in soil were determind in $\mathrm{Nu}-$ clear Materials Authority by gamma ray according to Matolin (1991).

The mature Aerva plants were segregated, into (roots, stems, leaves and flowers), dried at $70^{\circ} \mathrm{c}$ and representative portions were digested using mixture of $\mathrm{HClO}_{4}$ and $\mathrm{H}_{2} \mathrm{SO}_{4}$. The resultant solution was determined for $\mathrm{N}$, $\mathrm{P}, \mathrm{K}$ and $\mathrm{Fe}$ according to methods of Jackson (1973). Uranium was determined according to Bouda, (1988), Thorium was determined according to Chalmers (1970).

\section{RESULTS AND DISCUSSION}

The data presented in Tables ( $1 \& 2$ ) show that the sand fraction slightly decreased with increasing in distance the two sides in the two layers (surface and subsurface). While percentages of silt and clay fractions were slightly increased with increasing distances in surface and subsurface in both sides. Generally, sandy and sandy loam textures were found in the both two sides of Rosetta estuary.

Organic matter (O.M.) values in the investigated virgin soil samples were almost zero. It deserves to mention here that the organic matter percentage on western side at distance $300 \mathrm{~m}$ were $0.5 \%$ and $0.9 \%$ in the surface and subsurface sandy loam soils respectively. These results may be due to the arid climate conditions.

The investigated soil samples were slightly alkaline, as $\mathrm{pH}$ values ranged from 7.9 to 8.4 and from 7.8 to 8.0 in both the eastern and western Rostta sides, respectively.

It is quite evident that the electric conductivity (E.C.) at the western side was higher

Table 1 : Physical and chemical analyses of barren soil samples at Rosetta estuary area eastern side Northern Delta, Egypt

\begin{tabular}{|c|c|c|c|c|c|c|c|c|c|c|c|c|c|c|c|c|c|}
\hline \multirow[t]{2}{*}{ S. No. } & \multirow{2}{*}{$\begin{array}{c}\text { Distance } \\
(\mathrm{m})\end{array}$} & \multirow{2}{*}{$\begin{array}{l}\begin{array}{l}\text { Depth } \\
(\mathrm{cm})\end{array} \\
\end{array}$} & \multicolumn{3}{|c|}{$\begin{array}{l}\text { Particle size dis. } \\
\text { Sand }\end{array}$} & \multirow{2}{*}{\begin{tabular}{|l}
$\begin{array}{l}\text { Soil } \\
\text { textural } \\
\text { class }\end{array}$ \\
\end{tabular}} & \multirow{2}{*}{$\begin{array}{l}\text { O.M. } \\
\text { (\%) }\end{array}$} & \multirow{2}{*}{$\underset{\text { in soil paste }}{\mathrm{PH}}$} & \multirow{2}{*}{$\begin{array}{l}\text { E.C. } \\
\text { (dSfin) } \\
(1: 5)\end{array}$} & \multirow{2}{*}{$\begin{array}{c}\mathrm{CaCO}_{3} \\
(\%)\end{array}$} & \multicolumn{7}{|c|}{ Soluble ions meq / $100 \mathrm{gm}$ soil $(1: 5)$ extract } \\
\hline & & & Sand & $\begin{array}{l}\text { Silt } \\
\% \\
\end{array}$ & Clay & & & & & & $\mathrm{Ca}^{++}$ & $\mathrm{Mg}^{++}$ & $\mathrm{Na}^{+}$ & $\mathrm{K}^{+}$ & $\mathrm{HCO}_{3}$ & $\mathrm{Cr}$ & $\mathrm{SO}_{4}{ }^{-}$ \\
\hline \multirow[b]{2}{*}{1} & \multirow{2}{*}{100} & $0-30$ & 96.1 & 2.0 & 1.9 & Sandy & 0.0 & 8.0 & 7.9 & 0.54 & 1.9 & 3.20 & 2.43 & 0.58 & 2.0 & 5.2 & 0.86 \\
\hline & & $30-60$ & 96.1 & 2.0 & 1.9 & Sandy & 0.0 & 8.0 & 7.9 & 0.46 & 1.9 & 3.3 & 2.24 & 0.97 & 1.5 & 6.6 & 0.31 \\
\hline \multirow[b]{2}{*}{2} & \multirow[b]{2}{*}{150} & $0-30$ & 95.0 & 3.0 & 2.0 & Sandy & 0.0 & 8.4 & 7.2 & 1.03 & 1.3 & 3.8 & 2.36 & 0.67 & 1.5 & 5.6 & 1.73 \\
\hline & & $30-60$ & 96.1 & 2.0 & 1.9 & Sandy & 0.0 & 8.2 & 7.3 & 1.08 & 2.0 & 1.6 & 1.21 & 1.47 & 2.5 & 5.0 & 1.33 \\
\hline \multirow[b]{2}{*}{3} & \multirow[b]{2}{*}{200} & $0-30$ & 95.2 & 2.9 & 1.9 & Sandy & 0.0 & 8.3 & 7.0 & 0.99 & 1.5 & 2.5 & 0.88 & 0.52 & 1.5 & 1.6 & 0.70 \\
\hline & & $30-60$ & 95.2 & 2.4 & 1.9 & Sandy & 0.0 & 8.4 & 7.2 & 0.86 & 1.6 & 1.5 & 0.36 & 0.63 & 1.5 & 1.4 & 1.19 \\
\hline \multirow[b]{2}{*}{4} & \multirow[b]{2}{*}{250} & $0-30$ & 98.1 & 0.0 & 1.9 & Sandy & 0.0 & 8.0 & 2.0 & 1.24 & 0.8 & 1.9 & 0.37 & 0.52 & 1.0 & 1.4 & 1.19 \\
\hline & & $30-60$ & 98.1 & 0.0 & 1.9 & Sandy & 0.0 & 8.4 & 0.8 & 1.32 & 0.9 & 1.7 & 0.22 & 0.56 & 1.5 & 1.2 & 0.68 \\
\hline \multirow[b]{2}{*}{5} & \multirow[b]{2}{*}{300} & $0-30$ & 82.2 & 12.0 & 2.8 & Sandy & 0.0 & 7.9 & 2.9 & 1.0 & 2.0 & 1.2 & 0.30 & 0.60 & 1.5 & 1.5 & 1.10 \\
\hline & & $30-60$ & 82.2 & 11.2 & 6.9 & Sandy & 0.0 & 7.9 & 2.0 & 1.30 & 2.0 & 1.6 & 0.31 & 0.61 & 1.5 & 1.4 & 0.96 \\
\hline
\end{tabular}

Table 2 : Physical and chemical analyses of barren soil samples at Rosetta estuary area western side Northern Delta, Egypt

\begin{tabular}{|c|c|c|c|c|c|c|c|c|c|c|c|c|c|c|c|c|c|}
\hline \multirow{3}{*}{ S. No. } & \multirow{3}{*}{$\begin{array}{c}\text { Distance } \\
\text { (m.) }\end{array}$} & \multirow{3}{*}{$\begin{array}{l}\text { Depth } \\
(\mathrm{cm})\end{array}$} & \multicolumn{3}{|c|}{ Particle size dis. } & \multirow{3}{*}{$\begin{array}{l}\text { Soil } \\
\text { textural } \\
\text { class }\end{array}$} & \multirow{3}{*}{$\begin{array}{l}\text { O. M } \\
(\%)\end{array}$} & \multirow{3}{*}{$\begin{array}{c}\mathrm{pH} \\
\text { in soil } \\
\text { paste }\end{array}$} & \multirow{3}{*}{$\begin{array}{l}\text { E.C. } \\
\text { (dSim) } \\
(1: 5)\end{array}$} & \multirow{3}{*}{$\begin{array}{c}\mathrm{CaCO}_{3} \\
(\%)\end{array}$} & \multicolumn{7}{|c|}{ Soluble ions meq / $100 \mathrm{gm}$ soil $(1: 5)$ extract } \\
\hline & & & Sand & Silt & Clay & & & & & & \multirow[t]{2}{*}{$\mathrm{Ca}^{+}$} & \multirow[t]{2}{*}{$\mathrm{Mg}^{+}$} & \multirow[t]{2}{*}{$\mathrm{Na}^{+}$} & \multirow[t]{2}{*}{$\mathrm{K}^{+}$} & \multirow[t]{2}{*}{$\mathrm{HCO}_{3}^{-}$} & \multirow[t]{2}{*}{$\mathrm{Cl}$} & \multirow[t]{2}{*}{$\mathrm{SO}_{4}^{-}$} \\
\hline & & & & $\%$ & & & & & & & & & & & & & \\
\hline \multirow[b]{2}{*}{1} & \multirow[b]{2}{*}{100} & $0-30$ & 98.1 & 0 & 1.9 & Sandy & 0.0 & 7.9 & 1.9 & 0.41 & 0.9 & 2.2 & 2.43 & 0.37 & 1.5 & 3.1 & 1.3 \\
\hline & & $30-60$ & 98.1 & 0 & 1.9 & Sandy & 0.0 & 7.8 & 1.8 & 0.54 & 1.0 & 2.4 & 3.32 & 0.77 & 2.0 & 5.0 & 0.49 \\
\hline \multirow[b]{2}{*}{2} & \multirow[b]{2}{*}{150} & $0-30$ & 98 & 0 & 2.0 & Sandy & 0.0 & 7.8 & 2 & 0.61 & 0.82 & 2.9 & 4.20 & 0.86 & 2.0 & 6.2 & 0.76 \\
\hline & & $30-60$ & 97.2 & 0 & 2.8 & Sandy & 0.0 & 7.8 & 1.9 & 0.52 & 1.0 & 3.1 & 4.00 & 0.72 & 2.0 & 6.1 & 0.54 \\
\hline \multirow[b]{2}{*}{3} & \multirow[b]{2}{*}{200} & $0-30$ & 96.0 & 2 & 1.9 & Sandy & 0.0 & 7.9 & 1.8 & 0.41 & 0.9 & 2.6 & 1.69 & 0.86 & 1.5 & 4.5 & 0.05 \\
\hline & & $30-60$ & 96.0 & 2 & 1.9 & Sandy & 0.0 & 7.8 & 1.5 & 0.91 & 1.0 & 2.4 & 1.51 & 0.77 & 2.0 & 2.9 & 0.78 \\
\hline \multirow[b]{2}{*}{4} & \multirow[b]{2}{*}{25} & $0-30$ & 84.5 & 12 & 3.5 & Sandy & 0.0 & 8 & 1.9 & 0.54 & 1.4 & 0.91 & 1.32 & 0.44 & 2.0 & 1.9 & 0.17 \\
\hline & & $30-60$ & 85.3 & 12 & 2.7 & Sandy & 0.0 & 8 & 1.2 & 1.04 & 1.6 & 0.8 & 1.52 & 0.60 & 2.5 & 1.8 & 0.22 \\
\hline \multirow[b]{2}{*}{5} & \multirow[b]{2}{*}{300} & $0-30$ & 73.2 & 17 & 9.8 & S. Loam & 0.5 & 7.8 & 1 & 1.4 & 1.4 & 0.7 & 0.28 & 0.44 & 2.5 & 1.2 & 0.11 \\
\hline & & $30-60$ & 63.2 & 27 & 9.8 & S. Loam & 0.9 & 7.9 & 0.6 & 1.65 & 1.6 & 0.8 & 0.19 & 0.60 & 1.4 & 1.6 & 0.01 \\
\hline
\end{tabular}


than that obtained at the eastern side, in both surface and subsurface soil samples. In addition the (E.C.) values in surface soil samples were generally higher than that in subsurface, ones. These results may be due to water table level flocculated and soil texture changes. The results are agreed well with Bresler et al. (1982).

The soluble cations, data in Table $(1 \& 2)$ revealed that $\mathrm{Ca}^{++}$ions ranged between 0.8 to 2.0 meq / $100 \mathrm{gm}$ soil) and (0.8 to $1.6 \mathrm{meq} / 100$ gm soil) in soil samples of eastern and western sides, respectively. It is evident that the $\mathrm{Ca}^{++}$ions content in the surface soil sample were higher than that found in the subsurface, ones. The sodium found in the soil samples of the eastern and western sides of Rosetta estuary are affected by Mediterranean Sea actions. So, the highest $\mathrm{Na}^{+}$ ion values were found near Rosetta estuary, and the least ones far from it. The highest $\mathrm{Na}^{+}$ion value reached about $4.2 \mathrm{meq} / 100 \mathrm{gm}$ soil in Rosetta western side in the surface soil samples. Meanwhile, the least value $(0.14 \mathrm{meq} / 100 \mathrm{gm}$ soil) was found in the western side of subsurface soil samples at $300 \mathrm{~m}$ distance from Rosetta estuary.

The data showed that the soil that located near Rosetta estuary has low K-values especially in the surface layer, in other words, the subsurface ones has higher K-values concentrations. These results are in agreement with those of Aly et at. (1988), who found that potassium at the Mediterranean Sea on the shore zone was influenced by both thorium and uranium. So, potassium was higher near the Rosetta estuary than in the other soil samples

\section{Nutrient Status (N, P, K and Fe) in Soil Samples}

The data presented in Table (3) show that the available nitrogen, phosphorus and potassium values were generally low. This may be due to the light soil texture of the investigated soils (sand and sandy loom). On the other hand, the available iron content was high in the light soils. This trend depends on soil samples locations, heavy minerals content and iron content that usually found in black-sand (El-Fayoumy and Abdel Galil, 1988; Shukri, 1990; and Fathi et al., 1997).

With regard to the available N-content (Table 3 ), the data show that the highest value reached (15.50 meq / 100 gm soil) was found at a western side in surface and subsurface, ones. Meanwhile, the least $\mathrm{N}$-value (7.50 meq / 100 gm soil) was found in the surface soil sample of eastern side. The available N-values at Rosetta western side sample were generally higher than that obtained from other side for all locations surface and subsurface soil samples. These values increased with increasing distances from Rosetta estuary at the two sides, this may be attributed to the variations in ground water which get nearer to the soil surface or the sand dunes that found at the virgin soil. These results were confirmed by that reported by Olsen (1990) who found that the sandy soils have low $\mathrm{N}$-content and $\mathrm{N}$ in soil solution at the depth attributed to the relatively rapid movement of water through the profile of sandy soils.

The available phosphorus contents in the surface soil samples were higher than that in subsurface samples on the two sides. In addition, the available P-content in the western side was higher

Table 3: Available N, P, K, Fe of barren soil samples at Rosetta eastern and western Sides of Rosetta estuary area, Northern Delta, Egypt

\begin{tabular}{|c|c|c|c|c|c|c|c|c|c|c|}
\hline \multirow{2}{*}{$\begin{array}{l}\text { s. } \\
\text { No. }\end{array}$} & \multirow{2}{*}{$\begin{array}{l}\text { Distances } \\
\text { (m) }\end{array}$} & \multirow{2}{*}{$\begin{array}{l}\text { Depth } \\
\text { Cm }\end{array}$} & \multicolumn{4}{|c|}{ Eastern side } & \multicolumn{4}{|c|}{ Western side } \\
\hline & & & $\mathbf{N}$ & $\mathbf{P}$ & $\mathbf{K}$ & $\mathbf{F e}$ & $\frac{1100 \mathrm{~g}}{\mathbf{N}}$ & $\mathbf{P}$ & $\mathbf{K}$ & Fe \\
\hline \multirow{2}{*}{1} & \multirow{2}{*}{100} & $0-30$ & 7.50 & 0.21 & 0.58 & 1.18 & 10.00 & 0.14 & 0.77 & 1.27 \\
\hline & & $30-60$ & 8.50 & 0.19 & 0.68 & 0.85 & 10.00 & 0.13 & 0.77 & 1.09 \\
\hline \multirow{2}{*}{2} & \multirow{2}{*}{150} & $0-30$ & 8.75 & 0.10 & 0.58 & 0.88 & 13.75 & - & 0.60 & 0.72 \\
\hline & & $30-60$ & 9.30 & 0.07 & 0.67 & 0.89 & 13.75 & - & 0.80 & 0.38 \\
\hline \multirow{2}{*}{3} & \multirow{2}{*}{200} & $0-30$ & 10.00 & 0.22 & 0.87 & 0.69 & 11.25 & 0.34 & 0.87 & 0.47 \\
\hline & & $30-60$ & 10.60 & 0.18 & 0.88 & 0.55 & 13.73 & 0.35 & 0.98 & 0.51 \\
\hline \multirow{2}{*}{4} & \multirow{2}{*}{250} & $0-30$ & 10.25 & 0.17 & 0.44 & 0.53 & 11.25 & 0.37 & 0.52 & 0.25 \\
\hline & & $30-60$ & 10.50 & 0.13 & 0.31 & 0.59 & 12.50 & 0.30 & 0.60 & 0.24 \\
\hline \multirow{2}{*}{5} & \multirow{2}{*}{300} & $0-30$ & 12.80 & 0.13 & 0.56 & 0.51 & 15.50 & 0.24 & 0.35 & 0.38 \\
\hline & & $30-60$ & 12.5 & 0.13 & 0.60 & 0.37 & 15.50 & 0.30 & 0.44 & 0.38 \\
\hline
\end{tabular}


than that obtained in eastern side. The higher Pcontents were $(0.22$ and $0.37 \mathrm{meq} / 100$ gm soil $)$ and the lowers were $(0.07$ and $1.03 \mathrm{meq} / 100 \mathrm{gm}$ soil). These results agree well with that observed by Singh and Wren (1998).

The available K-content was slightly higher at the western side than that obtained at the eastern side, the higher available K-content were ( 0.98 and $0.88 \mathrm{meq} / 100 \mathrm{gm}$ soil) found in the western and eastern subsurface soil samples, in the same distance $(200 \mathrm{~m})$ from Rosetta estuary. The lower $\mathrm{K}$ - content ( 0.31 and $0.35 \mathrm{meq} / 100 \mathrm{mg}$ soil) were found in eastern subsurface and western surface soil samples, respectively. These results may be attributed to the soil texture and mineralogical composition of these areas, this in agree with EL Shazly et al. (1977).

The available Fe-content decreased with increasing distance from the two sides of Rosetta branch. Whereas, the Fe-content were sharply decreased with increasing distance at the western side, and slightly decreased with increasing distance at the other side of the estuary. These may be attributed to the existence of the black sand deposits that are found concentrated on the Rosetta mouth area and the area of black-sands that at the eastern side was extinct and larger than that at the western side. These results are in agreement with those of Kamel at al. ( 1973 ), Wassef ( 1973 ) and El Shazly et al. (1977). They reported that the high content of available Fe may be attributed to two reasons; firstly, the black- sand deposits were higher at the western side than the other side at the same distance, and secondly, the extent of many zones of rich heavy minerals content that related to the area around the Rosetta branch.

Total equivalent Thorium, equivalent Uranium, Potassium and Iron contents in the virgin soil samples

The equivalent Thorium (eTh) content in western side of Rosetta estuary was higher than that in eastern side. Meanwhile, the eTh contents in the eastern and western side surface soil samples were higher than that in the subsurface ones. Data of Tables (4 \& 5) showed that the higher eTh value were ( 77 and
$192 \mathrm{ppm}$ ) found in the eastern and western soil samples, respectively.

Table 4: Total thorium, uranium, potassium and iron contents in barren soil samples at Rosetta eastern side of Rosetta estuary area, Northern Delta, Egypt

\begin{tabular}{|c|c|c|c|c|c|c|c|c|c|}
\hline \multirow{2}{*}{$\begin{array}{l}\text { S. } \\
\text { No. }\end{array}$} & \multirow{2}{*}{$\begin{array}{c}\text { Distances } \\
(\mathrm{m})\end{array}$} & \multirow{2}{*}{$\begin{array}{c}\text { Depphh } \\
(\mathrm{mem})\end{array}$} & \multicolumn{2}{|c|}{ e Th } & \multicolumn{2}{|c|}{ eU } & \multicolumn{2}{|c|}{ K } & \multirow{2}{*}{$\begin{array}{l}\mathrm{Fe} \\
\%\end{array}$} \\
\hline & & & ppm & ${ }_{\mu \mathrm{H} / \mathrm{h}}$ & $\mathrm{ppm}$ & ${ }_{\mu \mathrm{R} / \mathrm{h}}$ & $\%$ & ${ }_{\mu \mathrm{R} / \mathrm{h}}$ & \\
\hline \multirow{2}{*}{1} & \multirow{2}{*}{100} & 0.30 & 77 & 23.87 & Uld & - & 0.54 & 0.81 & 19.0 \\
\hline & & $30-60$ & 23 & 7.13 & Uld & - & 0.67 & 1.05 & 19.2 \\
\hline \multirow{2}{*}{2} & \multirow{2}{*}{150} & 0.30 & 79 & 24.49 & 1 & 0.62 & 0.53 & 0.80 & 21.3 \\
\hline & & $30-60$ & 32 & 9.92 & 4 & 2.48 & 0.62 & 0.93 & 19.2 \\
\hline \multirow[b]{2}{*}{3} & \multirow{2}{*}{200} & 0.30 & 21 & 6.51 & 1 & 0.62 & 0.50 & 0.75 & 18.6 \\
\hline & & $30-60$ & 17 & 5.27 & 2 & 1.24 & 0.61 & 0.92 & 18.3 \\
\hline \multirow[b]{2}{*}{$4^{4}$} & \multirow[b]{2}{*}{250} & 0.30 & 14 & 4.34 & 3 & 1.86 & 0.43 & 0.65 & 18.1 \\
\hline & & $30-60$ & 9 & 2.79 & 1 & 0.62 & 0.53 & 0.80 & 15.2 \\
\hline \multirow[b]{2}{*}{${ }^{5}$} & \multirow[b]{2}{*}{300} & 0.30 & 14 & 4.34 & 2 & 1.24 & 0.78 & 1.25 & 12.9 \\
\hline & & $30-60$ & 8 & 2.48 & 2 & 1.24 & 0.83 & 1.17 & 12.5 \\
\hline
\end{tabular}

Table 5: Total Thorium, Uranium, Potassium and Iron Content in Barren Soil Samples of Rosetta Western Side of Rosetta estuary area , Northern Delta , Egypt

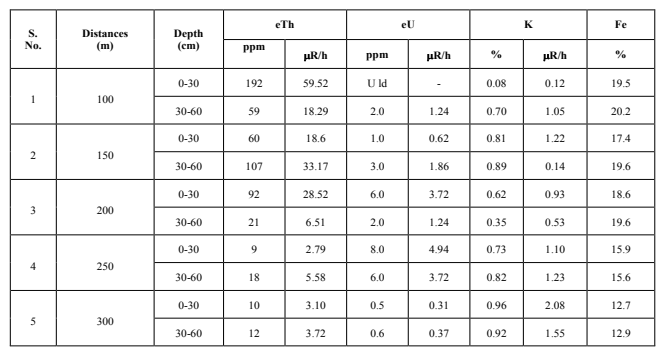

This observation may be attributed to radioactive minerals (zircon and monazite) that found in black-sand of Rosetta branch area, the heavy mineral concentrations at the western side were noticed to be more than that at the eastern side. As regard to the results of equivalent uranium content in Tables ( 4 \& 5), showed that they were under limit of detection (ULD) in the soil sample No.1 at both the surface and subsurface of the eastern side, and at surface soil sample of the western side. This may be due to the low content or absence of zircon and monazite minerals, due to the effect of the current of the Mediterranean Sea moving from the west to east. These results are in agreement with many authors such as Ammar et al. (1983) and Schulz(1995).

Regardless soil sample No.1 at eastern and western sides of Rosetta estuary it is quite evident that uranium values at western side ranged from $(0.5-8 \mathrm{ppm})$ were higher than that found at the eastern side, that ranged from 
( $1-4$ ppm). It is worthy to mention that the eU-content is found in the average world value (1-8 ppm). These may be attributed to the effect of leaching process, water table variation, Organic matter content, and soil texture. These results are in agreement with many authors ( IAEA, 1999).

The highest potassium values at the eastern $(0.83 \%)$ and western $(0.96 \%)$ sides soil samples were found at the distances $300 \mathrm{~m}$ in subsurface and surface soil samples, respectively. The K-content at the eastern side in subsurface soil samples were slightly higher than that obtained by surface ones. The K-content at the western side slightly increased with distance from Rosetta estuary. These results may be due to potassium - bearing minerals in the investigated soil samples. These results are in agreement with those of Aly et al., (1982) and Kabisheva (1993). They mentioned that field radioactivity is influenced mainly thorium, besides the potassium bearing parent materials

As regard to the total iron content, dated in Tables (4\&5) showed that the iron content decreased with increasing distances from the Rosetta estuary in the both two sides of soil samples. The higher total iron contents were ( $21.3 \%$ and $20.2 \%$ ) found in eastern surface and western subsurface soil samples, respectively the lower total iron content were ( $12.5 \%$ and $12.7 \%$ ) found in eastern and western subsurface and surface soil samples . It is clear that in western soil samples the iron in subsurface soil samples were slightly higher than that obtained in surface ones. Besides, the same trend was found in both two sides of the river. The higher contents were found near the Rosetta estuary and decreased with distances. These results attributed to the black sand deposits that found near estuary, (eastern and western) sides. These results were agreement with EL Fayoumy and Abdel Galil ( 1988 ). They showed that the heavy minerals concentrated at the western part of the Mediterranean
Sea coast compared to eastern part. The iron ores (Ilmenite, magnetite and hematite) are the main constituents of heavy fraction, and their distribution are located at / or near the Nile mouth.

\section{Nutrient Status ( N,P,K and Fe ) of Aerva Dry Matter}

As regard to the total N-content Tables (6 \& 7), the data showed that the highest value reached $(0.23 \%)$ was found in Aerva leaves that grown in western side at $200 \mathrm{~m}$. distance, and the lowest value $(0.02 \%)$ was obtained by Aerva flowers. That grown in western side at $300 \mathrm{~m}$ distance .It is clear that the higher Ncontent obtained by Aerva plants that grown at $200 \mathrm{~m}$ distances at two sides, and the lower Ncontent values were found in Aerva dry matter at $300 \mathrm{~m}$. of two (eastern and western ) sides. These results my be due to sea water and / or sand dunes. The N-content values of Aerva plant ( Roob , stem, leaves and flower ) that grown in western side, were slightly higher than that grown in other ( eastern ) side .

Table (6): Total N, P, K, Fe U and Th contents of Aerva dry matter that grown in virgin soil at eastern side of Rosetta estuary area, Northern Delta, Egypt

\begin{tabular}{|c|c|c|c|c|c|c|c|c|}
\hline \multirow{2}{*}{$\begin{array}{c}\text { S. } \\
\text { No. }\end{array}$} & \multirow{2}{*}{$\begin{array}{c}\begin{array}{c}\text { Distances } \\
\text { (m) }\end{array} \\
\text { (m) }\end{array}$} & \multirow{2}{*}{$\begin{array}{l}\text { Plant } \\
\text { parts } \\
\end{array}$} & \multicolumn{3}{|c|}{ Macro element (\%) } & \multicolumn{3}{|c|}{ Micro element $(\mathrm{ppm})$} \\
\hline & & & $\mathrm{N}$ & $P$ & $\mathrm{~K}$ & $\mathrm{U}$ & $\mathrm{Th}$ & $\mathrm{Fe}$ \\
\hline & \multirow{4}{*}{100} & Root & 0.05 & 0.08 & 0.03 & & 9.30 & 300 \\
\hline & & Stem & 0.06 & 0.07 & 0.05 & . & 3.80 & 179 \\
\hline & & Leaves & 0.03 & 0.02 & 0.06 & - & 1.20 & 130 \\
\hline & & Flowers & 0.06 & 0.02 & 0.05 & - & & 105 \\
\hline \multirow{4}{*}{2} & \multirow{4}{*}{150} & Root & 0.07 & 0.08 & 0.05 & 2.3 & 10.28 & 168 \\
\hline & & Stem & 0.12 & 0.08 & 0.02 & 2.1 & 3.13 & 65 \\
\hline & & Leaves & 0.10 & 0.06 & 0.08 & 1.20 & 1.30 & 45 \\
\hline & & Flowers & 0.17 & 0.13 & 0.06 & . & . & 30 \\
\hline \multirow{4}{*}{3} & \multirow{4}{*}{200} & Root & 0.09 & 0.09 & 0.02 & 0.9 & 6.90 & 210 \\
\hline & & Stem & 0.13 & 0.11 & 1.01 & 0.5 & 3.0 & 190 \\
\hline & & Leaves & 0.11 & 0.11 & 0.06 & . & 0.5 & 120 \\
\hline & & Flowers & 0.18 & 0.12 & 0.03 & & 0.03 & 30 \\
\hline \multirow{4}{*}{4} & \multirow{4}{*}{250} & Root & 0.08 & 0.010 & 0.03 & 0.90 & 1.30 & 170 \\
\hline & & Stem & 0.04 & 0.08 & 0.03 & 0.6 & 1.05 & 120 \\
\hline & & Leaves & 0.09 & 0.08 & 0.05 & & 0.51 & 25 \\
\hline & & Flowers & 0.20 & 0.03 & 0.02 & & 0.02 & 41 \\
\hline \multirow{4}{*}{5} & \multirow{4}{*}{300} & Root & 0.06 & 0.10 & 0.03 & 1.10 & 1.98 & 163 \\
\hline & & Stem & 0.03 & 0.08 & 0.02 & 1.00 & 0.92 & 120 \\
\hline & & Leaves & 0.04 & 0.10 & 0.03 & 1.00 & 0.5 & 26 \\
\hline & & Flowers & 0.08 & 0.10 & 0.03 & - & - & 25 \\
\hline
\end{tabular}


Table (7): Total N, P, K, Fe U and Th contents of Aerva dry matter that grown in virgin soil at western side of Rosetta estuary area, Northern Delta , Egypt

\begin{tabular}{|c|c|c|c|c|c|c|c|c|}
\hline s. & & Plant & & roelem & & & ment (p & \\
\hline No. & (m) & & $\mathrm{N}$ & $\mathrm{P}$ & $\mathrm{K}$ & & $\mathrm{Th}$ & $\mathrm{Fe}$ \\
\hline & 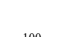 & Root & 0.09 & 0.02 & 0.04 & 1.00 & 8.36 & 360 \\
\hline & & Stem & 0.05 & 0.01 & 0.02 & 0.50 & 2.63 & 200 \\
\hline & & Leaves & 0.08 & 0.02 & 0.08 & 0.6 & 1.53 & 120 \\
\hline & & Flowers & 0.12 & 0.02 & 0.06 & & 0.3 & 120 \\
\hline & 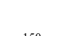 & Root & 0.10 & 0.03 & 0.03 & 1.41 & 9.2 & 350 \\
\hline & & Stem & 0.12 & 0.07 & 00.4 & 1.21 & 5.40 & 253 \\
\hline & & Leaves & 0.12 & 0.08 & 0.08 & 1.13 & 2.20 & 126 \\
\hline & & Flowers & 0.20 & 0.09 & 0.01 & & 1.20 & 110 \\
\hline & & Root & 0.18 & 0.09 & 0.03 & 3.50 & 8.20 & 190 \\
\hline & 200 & Stem & 0.19 & 0.11 & 0.02 & 2.1 & 6.9 & 140 \\
\hline & & Laveres & 0.23 & 0.21 & 0.08 & 2.5 & 2.1 & 80 \\
\hline & & Fowers & 0.21 & 0.20 & 0.06 & 0.5 & 0.9 & 33 \\
\hline & & Root & 0.10 & 0.02 & 0.09 & 5.2 & 6.2 & 143 \\
\hline & & Stem & 0.20 & 0.09 & 0.03 & 3.1 & 1.4 & 130 \\
\hline & & Leaves & 0.18 & 0.12 & 0.09 & 2.5 & 3.80 & 35 \\
\hline & & Fowers & 0.15 & 0.13 & 0.04 & 1.9 & & 35 \\
\hline & & Root & 0.04 & 0.08 & 0.03 & & 1.2 & 220 \\
\hline 3 & 300 & Stem & 0.04 & 0.06 & 0.04 & & 1.2 & 112 \\
\hline & & Leaves & 0.03 & 0.05 & 0.06 & & 0.5 & 42 \\
\hline & & Fowers & 0.02 & 0.19 & 0.05 & & 0.24 & 30 \\
\hline
\end{tabular}

On the other hand, the phosphorus content in Aerva dry matter that grown in eastern side was slightly higher than that found in the western side. The higher P-content ( Root, stem, leaves and flower ) of Aerva dry matter were found at $200 \mathrm{~m}$ distance at the two ( eastern and western ) sides. These may be attributed to the nitrogen that affected on p-uptake by plant. These results are in agreement with those of Hassan et al. (1973). They showed that P-uptake has been increased by $\mathrm{N}$, and Barthakur et al. (1980), who reported a significant increase in P-uptake by rice seedlings under submerged conditions in the presence of well decomposed cow dung added alone or combined with phosphorus.

Potassium content in Aerva dry matter data in Tables $(6 \& 7)$ showed that it is ranged between $(0.01 \%$ to $0.08 \%)$ and $(0.01 \%$ to $0.09 \%$ ) in the Aerva plant that naturally grown in eastern and western sides, respectively. It is clear that the $\mathrm{k}$-content in both blades and stems of Aerva plants increased more than that found by the other Aerva organs. Be- sides, k-content that obtained by Aerva plant in western sides were slightly higher than that obtained by the other side. These results agree with kandil et al. (1984).

The iron content of Aerva plant organs is very high, due to the presence of iron minerals (Ilmenite and Magnetite) that found in the Rosetta area .It is evident that the iron of Aerva plants at western side was higher than that found in eastern sides . Besides, the root iron content was two times higher than that obtained by the other organs.

As regard to total Fe-content of Aerva plants (roots, stems leaves and flowers), Tables ( $6 \& 7$ ) showed that the highest Fe-values are found at $100 \mathrm{~m}$ distance in both two sides. These attributed to the iron minerals ( ilmenite and magnetite ) that found in soil. The least $\mathrm{Fe}$-values are found at distance ( 250 and 300 $\mathrm{m}$ ) in eastern and eastern sides, respectively. These results are in agreement with those of Nouri et al. ( 1970 ) .

\section{THE RADIO NUCLIDES (URANIUM AND THORIUM ) IN THE ENVIRON- MENT COMPONENTS}

Regarding uranium and Thorium content in Aerva plant in western and eastern sides of the Rosetta branch, the concentration of uranium in plants that found at western side were shightly higher than that found in other side. The highest uranium content ( $5.2 \mathrm{ppm}$ ) was found in Aerva roots that grown in 250 $\mathrm{m}$ distance at western side of Rosetta branch . The Thorium content of the plant that grown in eastern side was slightly higher than that obtained in the other side. Regardless the first distances in two eastern and western sides, the Th-content in plants tend to decreased with increasing distance from the river in both sides. These results may be due to the heavy minerals contents. Such results agree with Ibrahim and Whicker (1989) who suggested that the concentrations of uranium and thorium measured in sail and plant under natural conditions was correlated with natural uranium and thorium. 


\section{REFERENCES}

Aly, H. H., Hossien, A. H. A. and Abd El-Gawad, H. A.,1988. Faba bean predication as affected by soil properties. Agric. Rec. Review, Egypt,66(4), 595-601.

Aly, M. M., Wassef, S. N., Yuanni, N.M., and Hathout, M.H.,1982. Natural field radioactivity correlated with thorium, uranium and radioactive potassium in beach sands of east Rosetta, Egypt. Desert Int. Bull., A.R.E., No. 1-2, 1-12.

Ammar, A.A., Wassef, S.N., Meleik, M.M.L. Fouad, K.M., and Dabbour, G.A., 1983. Remote, surface and laboratory detection of radioactive minerals of Rosetta black sand beach deposits.Egypt. Int. J. Remote Sensing.

Barthakur, H. P., Barua, T. C. and Barua R. C.,1980. Effect of organic matter and moisture levels on changes in redox-potential of a rice-field soil and uptake of phosphorus, iron and manganese by rice seedlings. J. Res., Assam Agric. Univ.

Bresler, E., Nacl, B. L., and Carter, D. L., 1982. Saline sodic soils. Springer-Verlag, 350-352.

Chalmers, R., A.,1970.Methods of Determination, translation (Ed.): Camern G .Ramsay Univ. of Aberdeen . Chapter 54. ,535-545.

Davidson, G.F.,1950. Contribution to the Nile deposits. Q.J.S. London,105,333-534.

El-Shazly, E. M., Ammar, A.A., Wassef, S.N., Meleik, M.L., Fouad, K.M. and Dabbour, G.A.,1977. Use of airborne radiometry, correlated with mineral assay, to study the distribution of black sand deposits, Rosetta area, Egypt. Euro. Assoc. Explor. Geophy. 39th meaning Zagreb Yugoslavia.

El Fayoumy, I . F . and Abdel Galil , M.,1988. Lithological characteristics of the Nile Delta beach and recognition of the buried Nile distributaries. Mans. Sci. Bull. 15 (2), 59-78

Fathi, A. I., Negm, M. A., Abdel-Aziz, S. M. and Hassan, H. M.,1997. Effect of organic manuring and zinc application on sorghum grown in a calcareous soil. Egypt. J. Agric. Rec., 70(1),1925
Hassan, H.M., Balba, A. M., and Abdon, P. M.,1973. Update of phosphorus by wheat plants from soil and fertilizer sources at different stages of growth as affected by nitrogen, fertilization. Isotope and Red. Res, 6,40-47.

Ibrahim, A. S., and Whicker, F. W.,1989. Plant / soil concentration ratio of $\mathrm{Ra}-226$ for contrasting sites around one active $U$ mine mill. Health Phys. ,54, $903-910$

International Atomic Energy Agency (IAEA) No. 186,1979. Gamma-ray surveys in uranium exploration technical reports series No. $(86,89)$ Vienna.

International Atomic Energy Agency (IAEA) No. 284 ,1988. Gamma-ray surveys in uranium exploration technical reports series No. $(86,89)$ Vienna, 151.

International Atomic Energy Agency (IAEA) No. 334,1999 . Gamma-ray surveys in uranium exploration technical reports series No. $(86,89)$ Vienna, 159.

Jackson, M. L.,1973. Soil Chemical Analysis. Constable and Co, Ltd., London.

Kabisheva, T. Z.,1993. Growth and metabolism by corn and peans in relation to nitrogen sources and salinization conditions .C.F. Chem. Abst. 79, No.1452.

Kamel, O. A., Rasmy, A. H., Khalil, A. and Bakir, R.,1973. Mineralogical analysis of black-sands at eastern part of east side3 Nile section. Ann. Geol. Surv. Egypt, III,227-247.

Kandil, A. A., Sultan, M. S. and Attia, A. M.,1984. Different response of corn (Zea Mays L) due to nitrogen, phosphorus and potassium fertilization. J. Agric. Sci. Mansoura Univ., 9,153-163.

Matolin, M.,1991.Construction and use of spectrometric calibration pads. EGY/4/030-30. Laboratory gamma-ray. Spectrometry .Report to the Government of the ARE by M. Matolin, IAEA Expert.

Nouri A. K. Hassan, Jons V. and Robert A.,1970. Influence of soil salinity on production of dry matter and uptake of nutrients in barley and corn. Agron. J.,62,43-45. 
Olsen, R. J.,1990. Fertilizer Nitrogen and Crop Rotation in relation to movement of nitrate nitrogen through soil profiles. Soil Sci. Soc. Amer. Pro. ,43,443-450.

Schulz, R. K.,1995. Soil chemistry of radionuclides .Health Phys. ,11,1317-1324.

Shukri, N. M.,1990. The mineralogy of some Nole sediments. Quart. J. Geol. Soc. London, 105, 511-534.
Singh, N. P. and Wren, M. E.,1998. Determination of alpha/emitting uranium Isotope in soft tissues by solvent extraction and alpha-spectrometry. Talonta, 20, 270-274.

Wassef, S. N.,1973. Distribution of monazite in the black-sands of Rosetta and Damietta and its conditions of sedimentations. Ph.D. Thesis, Fac. Sci., Ain Shams Univ., Cairo, Egypt.

$$
\begin{aligned}
& \text { ـ تأثير العناصر المشعة فى الرمال السوداء على النباتات البرية النامية شرق وغرب فرع رشئ الثيد }
\end{aligned}
$$

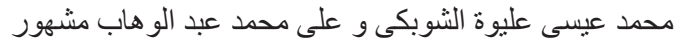

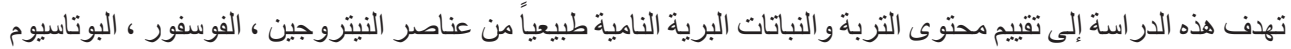

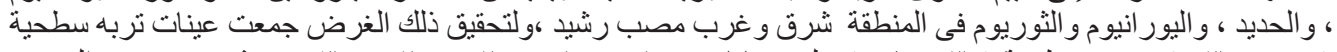

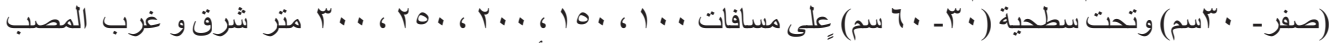

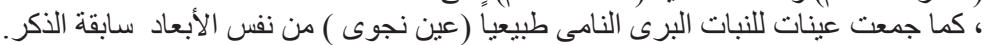

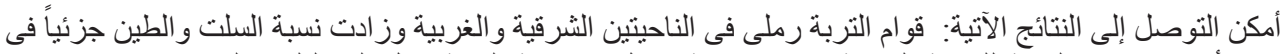

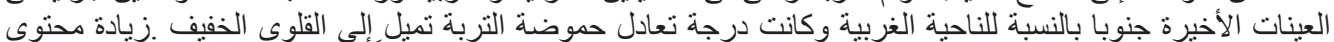

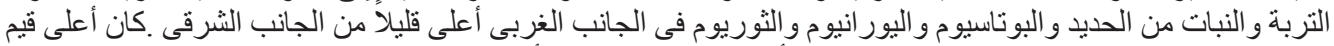

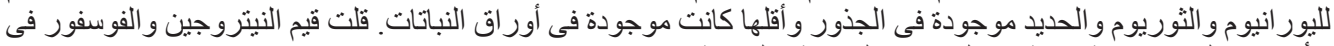
الأوراق و النبات بصفة عامة فى الناحيتين الثرقية و الغربية . 